\title{
Implementation of Model Problem Based Learning Assisted Media Powerpoint Benefits Materials Unity and Unity of the Nation to Improve the Nationalism and Patriotism of PKn in Class IV SDN Simomulyo III Surabaya
}

\author{
Ariana Kusuma Wardhani ${ }^{1}$ ), Suhanadji ${ }^{2}$ ), Rr. Nanik Setyowati ${ }^{3}$ ) \\ 1), 2), 3) Primary Education of Study Program, Postgraduate Student, State University of Surabaya
}

\begin{abstract}
The limitations of teachers applying educational value in accordance with this learning model are suspected to cause low nationalism, which is $56.25 \%$ or 18 of 32 students. Researchers use learning models based on problems as solutions to problems. The purpose of this research is 1) to improve the implementation of the PBL model in PKn-Learning to increase nationalism for students in grade IV-A SDN Simomulyo III $2020 / 2021,2$ ) to increase and to know the increase of nationalism in learning with the LBL model for students. Research is PTK, consisting of two cycles. The subject of this study is class IV students. Data collection techniques using questionnaire deployment, as well as observations and interviews as supporters. Based on the research results can be concluded that the implementation of the PBL model can increase $43.75 \%$ of the nasonalism of the class students. The increase can be seen from the percentage of the number of students who have attitude criteria, ranging from the initial condition of $56.25 \%$, Cycle $I$ is $93.75 \%$, and cycle II is $100 \%$. Improvements can be seen from the average student value. The initial condition is 74.87 , my cycle is 87.62 and cycle II 87.66.
\end{abstract}

\section{Keywords:- Nationalism Attitude, Learning-Based} Questions.

\section{INTRODUCTION}

Citizenship education is a subject that focuses on selfformation that is diverse in terms of religion, social culture, language, age and ethnic origin to become an Indonesian citizen who is intelligent, skilled, and characteristic mandated by Pancasila and the CONSTITUTION 1945. The materials contained in the curriculum of citizenship education include: The proclamation of Independence and the first constitution. The material is expected to provide awareness of the values of nationalism within the students to comply with the prevailing regulations. Based on the description it can be concluded that nationalism is one of the material of citizenship education, as a means to give the planting of nationalism values early on to students in school. The planting of nationalism values in students in schools is intended to create a succession of generations who are conscious of nationalism. Citizenship education as the mandate of the curriculum must result in a more psychological and socioultural change of behavior, especially as citizens who are aware of their rights and obligations as constitutionally mandated.

According to Susanto (2013:110) "Citizenship education is a subject that is used as a vehicle to develop and preserve the sublime and moral values rooted in Indonesian culture. Meanwhile, according to Sapriya et al (2009:45) Citizenship education should be developed to achieve the target to articulate the process of learning about, through the process, and to foster Indonesian constitutional democracy in accordance with the CONSTITUTION 1945, which is conceptually adapted from the concept of "learning about, through, and for democracy ". From the above definition can be concluded that citizenship education is a subject that focuses on the establishment of a citizen who understands and is able to exercise its rights and obligations to become a smart, skilled, and characteristic Indonesian citizen mandated by Pancasila and the CONSTITUTION 1945.

PKn Learning objectives in elementary school is to form the character or characteristics of a good citizen. According to Swandana in the school curriculum development Pioneer Project (2016:156), the objective of the citizenship education course is to make the students to:

$>$ To increase the knowledge or insight of learners of all things related to the life of society, nation, State, correctly through various ways or methods (cognitive aspects).

$>$ To build and establish the attitude of citizens who want and believe in the knowledge that has been obtained. Thus, knowledge that has been understood, believed, and internalized in the self or the soul of learners who will be his attitude in responding to the issues (attitude aspects).

$>$ Training citizenship skills to students to be a skilled citizen of democracy. This is done by familiarizing to the learners to behave in accordance with the values and norms that apply in the lives of everyday society. (psychomotor aspect). 
Based on the explanation above, it is understood that PKn subjects in elementary school play an important role in shaping the students into good citizens, who are citizens who know, want, and are aware of their rights and obligations.

The learning process is certainly not only developing students ' knowledge and understanding but also with the passion and the implementation (Azwar, 2011:4). The passion and the implementation of human beings are values, especially in the learning of PKn. All three aspects need to be balanced because of interrelated, so that the learning process of citizenship education in accordance with what is mandated by Pancasila and the CONSTITUTION 1945. Ideally, PKn learning is the cornerstone of forming attitudes and planting values in order to create strong nationalism, by presenting problems to the students.

However, the problem is that the expected condition has not been seen at SDN Simomulyo III Surabaya. The choir of State Elementary School in Simomulyo III, Surabaya encountered an error in pronunciation of Syair when singing the national anthem "Indonesia Raya" during the flag ceremony. Moreover, during the ceremony, $70 \%$ or about 434 students at SDN Simomulyo III were seen not in the ceremony. Rosita (2013:116) explains that the traits of nationalism divided into (1) have the love of homeland; (2) Proud to be part of Indonesia; (3) Placing the interests of the group rather than individual interests; and (4) acknowledge and appreciate diversity. In this case Pancasila and the song are outlined in the traits of nationalism.

Based on the observation of the process of teaching and learning activities in class IV, there are $85 \%$ or 28 students who can not memorize Pancasila and $15 \%$ from 34 students or about 6 students can not memorize the national anthem of Indonesia Raya. From Data Dissemination Questionnaire initial condition only 22 students or $64.70 \%$ of the total students have an understanding of willing to sacrifice, 18 students or $53.94 \%$ of students understand the attitude of unity and unity, 17 students or $50 \%$ of the total students there is the implementation of mutual respect, 17 students or $50 \%$ of the entire student there is the implementation of cooperation attitude, 17 students or $50 \%$ of the In addition, students are less enthusiastic to follow PKn-learning, which is seen from the absence of students who ask or propose opinions. Students tend to be passive in receiving teacher-provided material. In fact, to give opinions or ask questions still look shy and not spirit. Another character that appears is the students are still very picky in group formation because of incompatibility in making friends, so that the teacher needs to help in dividing into smaller groups. The above problem is not separated from the way teaching teachers who still use the method of Lecture on PKn lesson. Learning activities are dominated by teachers (student center) so that learning is only centered on the teacher not to students. Learning Media used by teachers also cannot improve student participation in learning. It is characterized by a rowdy atmosphere as the learning process progresses so that the teacher must reconditioned, this situation causes learning ineffective and efficiently. In addition, teachers do not instill attitudes contained in learning materials.

PKn-Learning at SDN Simomulyo III Surabaya tends to lecture methods that lead to cognitive aspects and provide information to students in a direction. Students become unaware of the problems in learning and the value inherent in learning. This has an impact on the decline in nationalism. The decrease in learning results was evident from the interview with the teacher on 11 December 2019. Researchers conducted interviews with PKn teacher at SDN Simomulyo III Surabaya, whose results proved that $55 \%$ of students in PKn-learning are still under the KKM, which is 75. This happens because in the opinion of the teacher, the material is taught too much, while the time provided is insufficient material. Therefore, based on the results of interviews and observations that have been conducted, students have received material about nationalism but have not been able to internalize and implement the value of nationalism.

Thus to develop problem-solving skills, as well as students become active learners in the learning activities so that the results are increasing, certain learning models need to be done. One way is to implement an issue-based learning model (PBM). According to Ibrahim (2012:99) problem-based learning (PBM) is an activity presenting to students an authentic and meaningful problem situation that can make it easy for them to conduct investigations and inquisers. With authentic problems presented as lesson content, students will be skilled in the Inenyelesaikan problems, especially the issues that are about state issues.

Problem-Based Learning Model (PBM) is the right alternative to solve the problem of learning outcomes of students in PKn learning because:

$>$ Model learning based on problems able to develop thinking and reasoned skills in solving problems, and in further development will develop creativity and independence. This is because students learn in the context of authentic problem solving (Marra, 2014:129).

$>$ Through learning with the presentation of problems, will be awakened instinct students to always want to know. Students will actively find a solution to the questions or problems presented.

$>$ With PBM understanding students will be built through experience. Students experience, do various activities to gain understanding. So learning will be more meaningful.

In addition, so that in learning does not happen verbalism, as well as students become enthusiastic in learning PKn should be used proper media because the media learning can lay the foundations of concrete and abstract concepts so as to reduce the understanding of verbalism, besides the media can generate motivation Belqiar learners (Sumantri, Mulyani and Johar Permana, 1998:134). 
The right medium used in the application of PBM models is the PowerPoint medium. Media PowerPoint is a projection media where learning messages are delivered through Views (Ibrahim, 2010:108). In learning with the PBM model the problem can be presented to students through slides that are packed with voice view, images, videos as well as interesting colors so that it can motivate them to engage actively in learning. The above problems led researchers to find learning models to improve the nationalism of the students, namely using the model of Problem Based Learning (PBL) is a learning that delivery is done by presenting a problem, asking questions, facilitating the investigation and opening the dialogue. This Model has the advantage to stimulate a mature ability in intellectuals (cognitive), covering the prudence in acting through problem analysis (affective and contemplative), and creating a learning experience. Students will become trained to learn without memorization. Based on the above advantages, the LBL is suitable for material related to nationalism, which is directly related to everyday life. Therefore, the Problem Based Learning model is expected to increase the understanding, passion, and execution of the material received. Furthermore, the discussion activities make students easier to understand the material with the group in living and implementing nationalism. Through discussion in groups can cultivate the value of unity and unity that is one characteristic of nationalism.

\section{METHOD}

\section{Types of research}

The type of research used is class action research (PTK). Characteristic of class action research is a specific action to improve the teaching and learning process in the classroom. Arikunto (2006:3) provides the definition that class action research is an concern for learning activities in the form of an action, intentionally raised and happening in a class together. The steps in PTK are called cycles of four stages, namely planning, implementation, observation, and reflection.

In this study, class action research was conducted in two cycles. The Stages in class action research are as follows (Wiratmaja, 2005):

- Planning.

- Implementation of

- Observation

- Reflection

\section{$>$ Time and place of research}

The research was conducted in April 2020 at SDN Simomulyo III. The reason for the selection of SDN Simomulyo III as the research site is because the researcher works. In addition, because students of SDN Simomulyo III have various characteristics of attitudes and suitable to be used as the subject of research.

\section{Subjec research}

The subject of this study is a grade IV-A student of SDN Simomulyo III. The number of grade IV-A SDN Simomulyo III is 32, all male students have low nationalism.

\section{$>$ Objecek research}

The object of this research is the improvement of nationalism in learning $\mathrm{PKn}$ with the problem based learning model IV-A SDN Simomulyo III.

\section{$>$ Design Research}

Preparation of class action research for students IV-A SDN Simomulyo III is as follows:

- Requesting permission to the head of SDN Simomulyo III to conduct research activities in the elementary school.

- To observe class IV-A SDN Simomulyo III to obtain an overview of the learning activities of citizenship education and the characteristics of its students.

- Conducting interviews with class teachers and some students of class IV-A SDN Simomulyo III.

- Identify existing issues in the class.

- Analyzing students ' learning issues on the material of nationalism on the subject of PKn.

- Formulate a problem.

- Formulating hypotheses.

- Develop research plans in each cycle

- Make an initial picture of the understanding, passion, implementation of the values of nationalism students of class IV-A SDN Simomulyo III.

- To review the indicators of Kompetesi, basic competencies and subject matter.

- Develop syllabus, Learning Plan, Student worksheet, and research instrument.

- Set up a Problem Based Learning method along with problems that will be used in the teaching.

\section{Collecting Techniques}

> The data collection techniques used in this study were with non-test techniques. Meanwhile, to know the initial conditions of the class is with interviews, observations and documentation.

\section{$>$ Interviews}

Interviews are a form of data collection techniques by means of dialogue conducted by the interviewer to the speakers. Before conducting a researcher interview prepare the instrument wawancarayangdisebut the interview guidelines. The content of questions or statements may include facts, data, knowledge, concepts, opinions, perceptions or evaluations regarding the focus of problems or variables examined in the study (Sukmadinata, 2011:216). Preparation of interviews in addition to drafting guidelines, the important thing is to cultivate a relationship either with a speaker or a respondent (Sukmadinata, 2011:217). A good relationship between interviewer and respondent will make it easier for respondents to answer the questions given and in the implementation of the interview 
is not very formal. Interviewers can develop questions according to the situation and conditions. In this study researchers asked directly to the teacher about the problem in relation to the nationalism.

\section{$>$ Observation}

Observation or observation is a technique or how to collect data by way of conducting observations on ongoing activities (Sukmadinata, 2011:220). Activities that are observed can be about how teachers teach, students learn, etc. The observation activities undertaken in this study are the observation of the condition and the students when the teaching and learning activities take place. As with interviews, before observing the researchers should prepare the observation guidelines. This aims to make it easier for researchers to observe the learning conditions that occur in the classroom. There are two types or formats of observation guidelines according to Sukmadinata (2011:221), i.e. the first, the grains of the activities that will be observed, in the implementation of observers make a brief description of the observed behavior. Second, contains the items of activity shown by the observed individuals. After discovering the problem then researchers reflect and look for solutions to the problem. So that researchers can finally do this research. In this study, researchers collaborated with teachers to observe the learning activities in the classroom. Observation is also done for initial condition data.

\section{$>$ Documentation}

Documentation is a technique of collecting data by collecting and analyzing documents, whether written documents, images, etc. (Sukmadinata, 2011:221). The documents gathered in this study are the drawings of the learning process. In addition to the images, researchers also collect student attitude assessment files found in Raport or other formats belonging to class teachers. The documents gathered to be analytical materials to find results related to the purpose of the study. Thus, the acquired documents will reinforce the analysis of the research results on each cycle.

\section{$>$ Questionnaire or poll}

Questionnaire or poll is a technique or means of indirect data collection (Sukmadinata, 2011:219). Data collection techniques using questionnaires, researchers do not need to directly ask respondents. The tool used in the collection of poll data is also called poll or questionnaire. Questionnaire or poll contains statements or questions.

\section{Instrument research}

The instrument research used in this research is a questionnaire sheet scale attitude, an observation sheet of the learning process that emphasizes on student activity, and guidelines for interviews to teacher classes.

\section{$>$ Intrument interview}

The interview instruments are used to retrieve complementary data related to the study. Researchers have prepared a format or sample of questions that can be used at the time of research.

\section{RESULTS AND DISCUSSION}

The discussion outlines the results of the study which covered the initial conditions, Cycle 1, and cycle 2, and its discussion. The following are results and discussions in the study:

Based on the observation that has been done to the teacher, students, and the learning process on the subject of PKn class IV-A SDN Simomulyo III, it can be seen that the learning of PKn is still conventional. It can be seen from the way teachers teach. How teaching teachers still uses conventional methods, which teachers use lecture methods during learning. Occasionally teachers do questions and answers with students while carrying textbooks. Teachers do not use media that supports the delivery of learning materials. Learning to be monotonous when students look bored with learning, even $25 \%$ of students do not memorize the national anthem (Indonesia Raya) and $12.5 \%$ of students do not memorize Pancasila. Rosita (2013) says that the traits of nationalism divided into (1) have the love of homeland; (2) Proud to be part of Indonesia; (3) Placing the interests of the group rather than individual interests; and (4) acknowledge and appreciate diversity. In this case Pancasila and the song are outlined in the traits of nationalism. From the results of the observation, researchers shared a scale questionnaire as early in class IV-A SDN Simomulyo III, to know the attitude of nationalism that students have The results of the study on the implementation of methods based on problems in the material unity and unity of the nation around us in class IVA SDN Simomulyo III Surabaya that can directly increase the activity and learning outcomes of students. Based on the findings obtained, the implications of the results of the study are: first, to seek that the headmaster also gives teachers a supply to use varied methods in each study, so as to increase the activity and learning outcomes of the students in each study. Second, strive to maximize the use of facilities and infrastructure in the school. The implication of this research can be described as follows:

\section{Learning based on problems}

A problem-based method is a learning method in which teachers provide or provide extensive guidance to students. On methods of learning based on this matter the teacher has given instructions on the material to be taught to students as needed. The results showed that the implementation of methods based on the problem affects the activity and learning outcomes of students, namely in the sub-theme of the unity and unity of the nation around us in class IV-A SDN Simomulyo III Surabaya.

This has implications for the future of school, especially the school principal should also observe the teachers ' activities during the study especially on the use of learning methods that must be adapted to the materials they teach so that they can improve their activities and learning outcomes. While in this research, where teachers teach the material of unity and unity of the nation using the right model of defense is a model based on problems. 


\section{Student Learning Activities}

Student learning activities are activities or behaviors that occur during the teaching and learning process, such as asking, asking opinions, working on tasks, answering teachers ' questions, and working with other students, and responsibilities to the tasks given. The results showed an increase in student activity depending on the teacher's activity during the learning process, which is the method or medium that teachers use during learning.

This implies that the teacher will have to understand how to improve student activity. Teachers should also often revise every completed study so that it can overcome all deficiencies and can later increase student activity in every learning.

\section{Student Learning Outcomes}

Learning outcomes are outcomes derived from learning activities. The results showed after the study of two cycles delivered by the teacher, namely by problembased methods, student learning outcomes in unity material and the unity of the nation become very good. It also contains implications for the future in addition to learning activities, teachers must also be able to improve student learning outcomes. Where students study outcomes at least $75 \%$ of students are well-done in their cognitive, affective and psychomotor learning outcomes. With the use of customized methods with the material let alone equipped with the use of the media of course to obtain the maximum learning results as expected will not be too difficult for teachers to make it happen.

Based on the results of the above discussion, research conducted by researchers with the title of implementation of methods based on problems to improve the learning outcomes of class IV students in the subtheme of the unity and unity of the nation around us at SDN Simomulyo III Surabaya is associated with several theories, that all research focus is already in accordance with the theory. In the study the purpose and hope of researchers who have not achieved on the learning cycle I can already be achieved and be good or very good at cycle II.

The results of the above studies also show awkward or strangeness where some of the strangest ones are the most bizarre of the activities and student learning outcomes that are too fast that make the teacher of the class acting as an observer wonder over the results achieved by the students. But the Observer believes that increasing the activity and learning outcomes that students obtain is due to the use of interesting methods and in accordance with the material being taught. The results of research from the initial study to cycle II if shown in the form of the matrix as in table 1. below.

\begin{tabular}{|c|c|c|c|c|}
\hline \multirow{2}{*}{ Number } & \multirow{2}{*}{$\begin{array}{l}\text { Research } \\
\text { Focus }\end{array}$} & \multirow{2}{*}{$\begin{array}{l}\text { Preliminary study } \\
\text { Results }\end{array}$} & \multicolumn{2}{|c|}{ Research results } \\
\hline & & & Cycle I & Cycle II \\
\hline \multirow[t]{5}{*}{1} & \multirow[t]{5}{*}{$\begin{array}{l}\text { Learning } \\
\text { learning based } \\
\text { on problems }\end{array}$} & \multirow[t]{5}{*}{ Not using } & $\begin{array}{l}\text { Orienting students on a } \\
\text { problem and drafting a } \\
\text { hypothesis needs little } \\
\text { improvement }\end{array}$ & $\begin{array}{l}\text { Orient students to a problem and a very } \\
\text { good hypothesis drafting }\end{array}$ \\
\hline & & & $\begin{array}{c}\text { In organizing the students to to } \\
\text { design the experiments } \\
\text { according to the steps is still } \\
\text { low }\end{array}$ & $\begin{array}{c}\text { In organizing the students to design an } \\
\text { appropriate experiment-the steps are } \\
\text { very good }\end{array}$ \\
\hline & & & $\begin{array}{c}\text { Guiding students to conduct a } \\
\text { good investigation }\end{array}$ & $\begin{array}{c}\text { Guiding students to do excellent } \\
\text { investigations } \\
\end{array}$ \\
\hline & & & $\begin{array}{l}\text { Activities in developing and } \\
\text { presenting guiding students to } \\
\text { obtain information through } \\
\text { trials need to be revised }\end{array}$ & $\begin{array}{l}\text { Activities in developing and presenting } \\
\text { guide students to get information } \\
\text { through excellent experiments }\end{array}$ \\
\hline & & & $\begin{array}{l}\text { Teachers too fast in analyzing } \\
\text { and evaluating in the process of } \\
\text { making conclusions }\end{array}$ & $\begin{array}{l}\text { Analyzing and evaluating the process of } \\
\text { making conclusions very well and } \\
\text { facilitating students in formulating the } \\
\text { principles and generalization of its } \\
\text { findings }\end{array}$ \\
\hline \multirow[t]{5}{*}{2} & \multirow{5}{*}{$\begin{array}{l}\text { Student } \\
\text { activity in } \\
\text { learning }\end{array}$} & $\begin{array}{c}\text { Low student } \\
\text { Attendance } \\
\end{array}$ & Student attendance is still low & Excellent student Attendance \\
\hline & & $\begin{array}{l}\text { Few students pay } \\
\text { attention to the teacher }\end{array}$ & $\begin{array}{l}\text { Noticed when described quite } \\
\text { well }\end{array}$ & Pay attention when explained very well \\
\hline & & $\begin{array}{l}\text { Ask or respond to } \\
\text { questions still low }\end{array}$ & $\begin{array}{l}\text { Asking or responding to } \\
\text { questions began to increase }\end{array}$ & $\begin{array}{c}\text { Asking or responding to questions is } \\
\text { good }\end{array}$ \\
\hline & & $\begin{array}{l}\text { Discussions or group } \\
\text { questions are still low }\end{array}$ & $\begin{array}{l}\text { Discussing and questioning in } \\
\text { the group is good }\end{array}$ & $\begin{array}{c}\text { Discussing and questioning is quiet and } \\
\text { very good }\end{array}$ \\
\hline & & Trying to find a low & Trying to find a reference is & All students seek references from other \\
\hline
\end{tabular}


ISSN No:-2456-2165

\begin{tabular}{|c|c|c|c|c|}
\hline \multirow{4}{*}{ Number } & \multirow{4}{*}{$\begin{array}{l}\text { Research } \\
\text { Focus }\end{array}$} & \multirow{2}{*}{$\begin{array}{l}\text { Preliminary study } \\
\text { Results }\end{array}$} & \multicolumn{2}{|c|}{ Research results } \\
\hline & & & Cycle I & Cycle II \\
\hline & & $\begin{array}{c}\text { reference (all using } \\
\text { only the book } \\
\text { package) }\end{array}$ & good enough & sources \\
\hline & & $\begin{array}{l}\text { Almost all students do } \\
\text { not timely finish their } \\
\text { duties }\end{array}$ & $\begin{array}{l}\text { (have already started to borrow } \\
\text { to the library) }\end{array}$ & $\begin{array}{l}\text { All students seek references from other } \\
\text { sources }\end{array}$ \\
\hline \multirow[t]{3}{*}{3} & \multirow[t]{3}{*}{$\begin{array}{c}\text { Student } \\
\text { Learning } \\
\text { Outcomes }\end{array}$} & $\begin{array}{c}\text { Cognitive: } \\
\text { Students are being } \\
\text { completed }(35 \%) \\
\end{array}$ & $\begin{array}{c}\text { Cognitive: } \\
\text { High finished students }(62.5 \%)\end{array}$ & $\begin{array}{c}\text { Cognitive: } \\
\text { Students completed very high }(85 \%)\end{array}$ \\
\hline & & $\begin{array}{c}\text { Affective: } \\
\text { Students are good } \\
(40 \%)\end{array}$ & $\begin{array}{c}\text { Affective: } \\
\text { High students }(75 \%)\end{array}$ & $\begin{array}{c}\text { Affective: } \\
\text { Excellent students very high }(95 \%)\end{array}$ \\
\hline & & $\begin{array}{l}\text { Psychomotor: Students } \\
\text { both moderate }(47.5 \%)\end{array}$ & $\begin{array}{l}\text { Psychomotor: High students } \\
(77.5 \%)\end{array}$ & $\begin{array}{c}\text { Psychomotor: Excellent students very } \\
\text { high }(95 \%)\end{array}$ \\
\hline
\end{tabular}

Table 1:- Matrix of research Results

\section{CONCLUSION}

In learning in early studies teachers have not used learning models based on problems. In the I cycle the teacher activity is already applying according to the syntax towards the students, but it needs a slight improvement, in the II cycle of syntax in learning based on the problems taught by the teacher is good. Application of learning model based on problem in class IV SDN Simomulyo III Surabaya can increase student activity in Subtema unity and unity of the nation around us in the class. Where the students ' activities are classifying gradually, i.e. early studies are still low, cycle I medium, Cycle II is good. The classical guidance on student learning outcomes in the students ' affective Realm also showed a fairly significant increase in the initial study of moderate $(48 \%)$, in the high I cycle $(78 \%)$, and increased in the very high II cycle to $94 \%$. The above Data illustrates that the method of learning based on problems in this research is able to complete the learning results on the affective with excellent categories. The results of the study proved according to experts ' opinions and previous studies. Thus, the learning model based on the problem proved very appropriate to be applied in the study of material unity and the nation's inunit in grade IV students SDN Simomulyo III Surabaya.

\section{SUGGESTION}

For teachers who want to improve student learning outcomes with low student motivation, teachers can apply learning models based on problems. In a learning should teachers orientate problems to students, tailored to the experience and circumstances of the environment. If a teacher implements a learning model based on an ammissible learning, it should be when the group formation must be split up so that the experiment can run as expected. Teachers always give each student the opportunity to ask and respond to questions without choosing a clever student. But students who are not too clever are given the opportunity also to ask and respond to questions from the teacher. In conducting learning should teachers always give praise to students, do not reproach, give a positive response to students ' questions and opinions, the arena of praise will increase the activity and satisfaction of the students.

\section{REFERENCES}

[1]. Arikunto,S. (2006).Dasar-dasar

Evaluasi Pendidikan.Jakarta: PT.Bumi Aksara

[2]. Azwar, S. (1995). Sikap Manusia Teori dan Pengukurannya. Yogyakarta:Pustaka Belajar.

[3]. Azwar, S. (2011). Sikap Manusia Teori dan Pengukurannya. Yogyakarta:Pustaka Belajar.

[4]. Margono. (2003). Metodologi Penelitian. Jakarta:Bumi Aksara.

[5]. Masidjo, I. (1995). Penilaian Pencapaian Hasil Belajar Siswa di Sekolah. Yogyakarta: Kanisius.

[6]. Masidjo, I. (2010).Penilaian pencapaian hasil belajar siswa disekolah. Yogyakarta: Kanisius.

[7]. Ridwan. (2014). Pembelajaran Saintifik untuk Implementasi Kurikulum 2013. Jakarta: Bumi Aksara.

[8]. Rosita. (2013). Hubungan Pemahaman Bela Negara dengan Nasionalisme Siswa di SMP Negeri 3 Tambun: FKIP UNJ. Diakses dari http://digilib.unj.ac.id/pengguna

[9]. Sugiyono. (2011). Metode Penelitian Kuantitatif, Kualitatif, dan RnD. Bandung: Alfabeta

[10]. Sukardinata.(2008).Metodologi Pendidikan,Kompetensi

Penelitian

Praktiknya.Jakarta:PT.Bumi Aksara.

[11]. Sukardinata.(2010).Evaluasi Pendidikan,Prinsip dan Operasionalnya.Jakarta:PT.Bumi Aksara.

[12]. Wiraatmadja,(2006).Metode Penelitian Tindakan Kelas.Bandung: Remaja Rusdakarya.(13) 